岡山医誌（1994）106，1１0

\title{
日本人における $\mathrm{RB} 1$ 遺伝子第 $17 お よ ひ ゙ 20$ 番イントロン 内 VNTRの多型性の検討および遺伝性網膜芽細胞腫に おける遺伝相談への応用
}

\author{
岡山大学医学部小児科学教室（指導：清野佳紀教授）
}

二 宮 伸 介

(平成 5 年 10 月 7 日受稿)

Key words：網膜芽細胞腫, VNTR, 多型, PCR, 遺伝相談

\section{緒言}

網膜芽細胞腫 $(\mathrm{Rb})$ は, 出生 20,000 人に 1 人 の頻度で網膜に発生する小児の悪性腫瘍であ る”. 本腫愓は常染色優性遺伝様式を示す遺伝性 （30\%）と非遺伝性（70\%）のものとに分類さ れる．両側発生の腫嗙がすべて遺伝性なのに対 し，片側発生の腫楟は多く（84\%）は非遺伝性 で一部（16\%）は遺伝性である2．Rbの発生機 序は, Two-hit theory で説明される ${ }^{3)}$.すなわ ち, 遺伝性のものでは, 生殖細胞において癌抑 制遺伝子である網膜芽細胞腫遺伝子（RB1）の 一方の対立遺伝子に突然変異が起こり,ついで 体細胞（網膜芽細胞）に染色体異常や遺伝子再 編成により他方の対立遺伝子に欠失や突然変異 が起こると，两側多焦点性に腫場が発生する.

一方, 非遺伝性の $\mathrm{Rb}$ では, 体細胞の 2 つの対立 遺伝子に 2 回の突然変異が起こるために, 片側 単焦点性に腫瘍が発生する. Rb 罹患した体質性 染色体異常症の研究より, RB1 の遗伝子座位は 13q14バンドに決定されていたが4), 1980年代後半 になり RB1 遺伝子がクローニングされた55。本

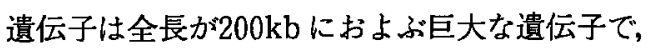
27個のエクソンを含むことが明らかにされた6).

$\mathrm{Rb}$ では早期診断と早期治療により視力を温存 できるので，とくに，遺伝性の $\mathrm{Rb}$ の保因者に おける発症前診断は重要な課题となっている。 しかし, 遗伝性 $\mathrm{Rb}$ では点突然変異あるいは微
細な欠失が主たる原因でありク，全エクソンの配 列解析による遺伝子診断には莫大な労力を要し, 実用的とはい之ない，このような理由から，遺 伝性 Rb では RFLP（制限醉素切断 DNA 断片 の多型性）を用いた遺伝子診断が一般的に用い られている ${ }^{8)}$ この際, 目的とする遺伝子そのも のの多型性を応用すれば，減数分裂における組 み替えを無視でき，診断の精度は $100 \%$ である。 VNTR (variable number of tandem repeat) はゲノム DNA 中で一定数の塩基配列が繰り返 し構造をとるもので，しかも，その繰り返しの 数は個人によって異なるため, 個人を識別する 非常に有効な遺伝標識として注目されている9.

本研究は遺伝性 $\mathrm{Rb}$ において実用的な発症前 遺伝子診断法を開発することを目的として，日 本人において RB1 遺伝子第17および20番イン トロン内に存在するVNTRを PCR (Polymerase chain reaction) 法により增幅しその多型性 の種類と頻度とを検討した。 また，この多型性 を遺伝性 $\mathrm{Rb} 3$ 家系における発症前診断や染色 体欠失の親の起源の決定に応用した。

\section{対象と方法}

1. 対象

日本人における RB1 第17および20番イント ロン内 VNTRの多型性の頻度を検討するため, 遺伝的に無関係の正常日本人50例（男性26人， 女性24人, 年㱓24～48歳)を対象としてDNAを 
抽出した.これらのイントロン内の VNTR 多 型性の解析を, 以下に述べる遺伝性の $\mathrm{Rb} の 3$ 家系で, $\mathrm{Rb}$ の発症前診断あるいは染色体欠失の 親の起源の決定に応用した。

1) 家系 1 (図 1 a)

相談者 (II - 3) は第 3 子の新生児女児. 父親 （I－1）は片側性 Rb で眼球摘出を受けた. 第 1 子（II-1）は男児, 両側性 Rbのため生後 6 か月で左側の眼球摘出と右側の網膜凝固術を受 けた. 体細胞および腫汮細胞の染色体分析は正 常であった，視神経末端の腫痬細胞浸潤はなか つたが, Cyclophosphamide と Vincristine の 化学療法を 1 年間受け, 完全寛解を続行してい る. 第 2 子（II-2）は現在 5 歳で, $\mathrm{Rb}$ の発生 は認められなかった。

2) 家系 2 (図 1 b)

相談者（II-2）は第 2 子の生後 3 歳の男児. 父親 (I-1) が両側 $\mathrm{Rb}$ で, 両眼球摘出を受け た. 第 1 子 (II-1) の女児は生後 3 か月で両側 $\mathrm{Rb}$ を指摘され, 右眼球の摘出と左眼球の網膜凝 固術を受けた. 第 2 子は男児で, 現在まで $\mathrm{Rb} の$ 発生が認められないが, 両親が発症前診断を希 望した. 第 1 子の体細胞および腫瘍細胞の染色 体分析はいずれも正常であった。

3) 家系 3

発端者は正常な両親 (父親34歳, 母親29歳) から生まれた第 2 子の男児. 生後 4 か月の時, 两側吸b を指摘され，右側眼球摘出および左側 網膜凝固術を受けた，表現型にはとくに異常を 認めなかったが, 染色体分析で13番染色体長腕 部分欠失が認められた. 高精度分染法により核 型は，46, XY, del(13) (q14.3q21.4) と同定さ れた（図 2)。腫瘍細胞の染色体分析は正常であ (a)

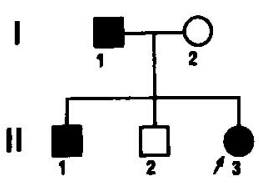

(b)

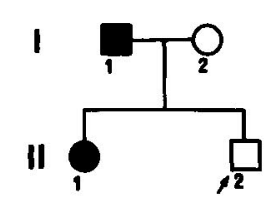

図 1 遺伝性 $\mathrm{Rb}$ の家系、 $\mathrm{a}$ は家系 1. $\mathrm{b}$ は家系 2 矢印は相談者を, 黒ぬり記号は $\mathrm{Rb}$ 㭧者を示 す.
った。なお，両親の染色体は正常であった，生 後 6 歳で, 境界領域の精神遅滞と著明なアトピ 一性皮庯炎が認められた。染色体異常の親の起 源を決定するために, 家族の承諾を得て, 遺伝 子診断を施行した。

2. 方法

1) D N A の抽出

末梢血白血球よりフェノール・クロロホルム 法あるいは Jeanpiere の迅速 DNA 抽出法 ${ }^{10)}$ 用い，DNA を抽出分離した，後者の方法では， 混入した蛋白を除去するため，さらにフェノー ル・クロロホルムでDNAを精製した. DNA 濃 度を $260 \mathrm{~nm} に お け る$ 吸光度より測定した。

2 ) 分子遺伝学的方法

(1)RB1 第17番イントロン内 VNTR の PCR 法による増幅

Scharf らの方法"11に従い, RBD12（5'CCTAACGTATGGCCAAGTTTCC- 3 ') およ び RBD13 ( 5 '-GCTAAACCATTCATGAGGGAT- 3 ')の 2 つの oligonucleotides を Applied Biosystems 社製の DNA 合成器で作製し, プ ライマーとして用いた. PCR 法の反応系は総量 $100 \mu \mathrm{l}$ で, ゲノム DNA $1 \mu \mathrm{g}, \mathrm{dNTP} 100 \mu \mathrm{M}$, 各プライマー0.5 $\mu \mathrm{M}, \mathrm{MgCl}_{2} 1.5 \mathrm{mM}$, Taq polymerase $2.5 \mathrm{U}$, Tris- $\mathrm{HCl} 10 \mathrm{mM}$, TritonX$1000.1 \%$ を含有する. PCRの条件として, denature $94^{\circ} \mathrm{C}$, annealing $55^{\circ} \mathrm{C}$, extension $72^{\circ} \mathrm{C}$

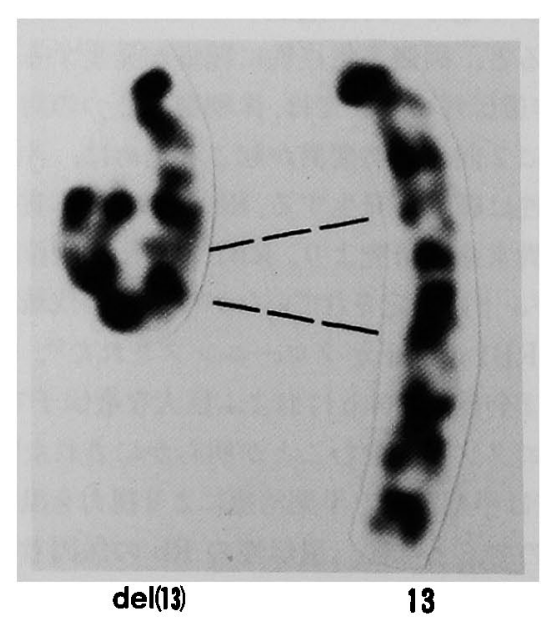

园 2 家系 3 の患児の末梢血染色体部分核型 
それぞれ1分間を，アステック社のサーマルサ イクラーで30サイクル施行した. PCR 增幅産物 を $0.2 \mu \mathrm{g} / \mathrm{ml}$ エチジウムブロマイドを含む $1.5 \%$, アガロースゲル $11.5 \times 12.5 \mathrm{~cm} て ゙ 20 \mathrm{~mA}, 4$ 時間電 気泳動した後, 柴外線下でポラロイドフィルム で撮影し, PCR 産物の塩基長を決定した. 分子 量マーカーとして100bp-ladder(Pharmacia 社) を使用した。

(2)RB1 第20番イントロン内 VNTR 領域の PCR 法による増幅

第20番イントロン内の VNTR の増幅には Yandell と Dryja の方法 ${ }^{12)}$ 改変した Brandt らの方法 ${ }^{13)}$ 用いた.プライマーとしては primer

\section{$\begin{array}{llllll}1 & 2 & 3 & 4 & 5 & \mathbf{M}\end{array}$}

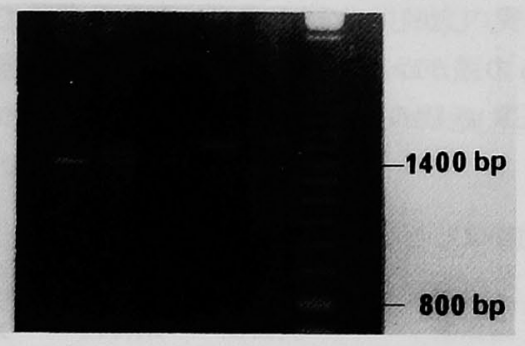

図 3 第17番イントロン内 VNTR の多型性

Mはマーカー,レーン 1 は $1400 \mathrm{bp}$ のホモ接合

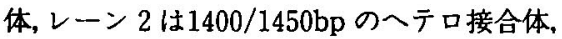
レーン 3 は1400/1500bpのへテロ接合体, レ ーン 4 は $1500 \mathrm{bp}$ のホモ接合体, レーン 5 は 1500/1550bp のへテロ接合体を示す.

表 1 RB1 第17番イントロン VNTR 遗伝型の恝 测值と期待值とのカイ 2 垂検定

\begin{tabular}{lrrr}
\hline 遺伝型(bp) & 実測値 & 期待値 & $\boldsymbol{x}^{2}$ 值 \\
\hline $1400 / 1400$ & 26 & 26.65 & 0.01 \\
$1400 / 1450$ & 1 & 0.73 & 0.01 \\
$1400 / 1500$ & 20 & 17.52 & 0.36 \\
$1400 / 1550$ & 0 & 1.46 & 1.46 \\
$1450 / 1450$ & 0 & 0.01 & 0.01 \\
$1450 / 1500$ & 0 & 0.24 & 0.24 \\
$1450 / 1550$ & 0 & 0.02 & 0.02 \\
$1500 / 1500$ & 1 & 2.88 & 1.23 \\
$1500 / 1550$ & 2 & 0.48 & 4.81 \\
$1550 / 1550$ & 0 & 0.02 & 0.02 \\
\hline
\end{tabular}

$\chi^{2}=8.25, \mathrm{df}=9, \mathrm{p}=0.5$
310 ( 5 '-AAGTAAGAAAATCAAGCACTT3')および primer103 (5'-AATTAACAAGGTGTGGTGGT- 3 ') を使用し, 反応系は $50 \mu 1$ で, ケノム DNA $0.5 \mu \mathrm{g}, \mathrm{dNTP} 200 \mu \mathrm{M}$, 各プ ライマー-1 $\mu \mathrm{M}, 5 \%$ ホルムアミド, $\mathrm{MgCl}_{2} 1.5 \mathrm{mM}$, Taq polymerase $1.25 \mathrm{U}$, Tris- $\mathrm{HCl} 10 \mathrm{mM}$, Triton X-100 0.1\%を含有する. PCR の条件 は, 最初の denature $94^{\circ} \mathrm{C}$ を 分間行った後, denature $94^{\circ} \mathrm{C} 15$ 秒, annealing $52^{\circ} \mathrm{C} 15$ 秒, extension $71^{\circ} \mathrm{C} 30$ 秒を 35 サイクル行い, 最後に annealing $52^{\circ} \mathrm{C} 1$ 分間, extension $71^{\circ} \mathrm{C} 3$ 分間を施行 した. PCR 産物 $10 \mu \mathrm{l}$ を制限醭素 BstNI 10単位, $60^{\circ} \mathrm{C} て ゙ 3$ 時間消化し, non-repeat 部分を切断し た.つぎにこの消化物 $3.5 \mu 1$ と同量の色素液 (0.05\% Xylenecyanol, 2.5\% Ficoll 400, 1.5 mM EDTA）とを混合し，12\%ポリアクリルア ミドゲル $10 \times 10 \mathrm{~cm}$ を用い， $150 \mathrm{~V} ， 2$ 時間電気 泳動した.ゲルを銀染色キット(第一化学薬品) で染色し塩基長を決定した，分子量マーカーと して100 bp-ladder を用いた.

3 ) 統計学的方法

出現頻度の統計学的分析にはカイ 2 乗検定を 用い, $\mathrm{p}<0.05$ を有意とみなした。

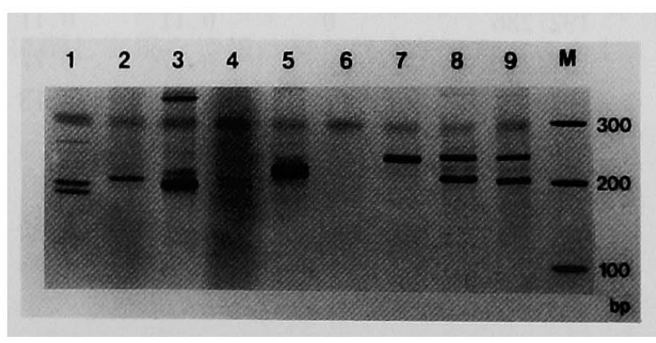

図 4 第20番イントロン内 VNTR の多型性 Mはマーカー, レーン 1 は192/200bpのへテ 口接合体, レーン 2 は208/208bp のホモ接合 体, レーン 3 は196/240bpのへテロ接合体, レ ーン 4 は196/208dpのへテロ接合体, レーン 5 は216/224bpのへテロ接合体，レーン 6 は 増幅なし、レーン 7 は236/240bp のへテロ接 合体, レーン 8 は204/240bp のへテロ接合体, レーン 9 は208/240のへテロ接合体を示す. 


\section{結果}

1. 正常日本人における第17番イントロン内 VNTR の多型性

Scharf らの原法"1では26 28サイクルでもっ とも増幅の効率が良好で特異性が高いと報告さ れているが，本研究では30サイクルが增幅と特 異性の 2 点で優れていた．本 VNTR の基本骨 格は54bp の繰り返し構造であるので, PCR 産 物の塩基長を，アガロース電気泳動における增 幅産物の 100 bp-ladder マーカーとの位置関係か ら約 $50 \mathrm{bp}$ 間隔で恣意的に定義した. 正常日本人 50 症例の第 17 番イントロンの VNTR には 1400 bp，1450bp，1500bp および1550bpの 4 種類の 対立遺伝子が存在しており (図 3)，その出現頻 度はそれぞれ0.73，0.01，0.24および0.02であ った．異なった対立遗伝子のへテロ接合体の場 合にも，增幅産物の染色強度は均等であった。
また，本論文にはデーターを示さないが，これ らの対立遺伝子は codominantに遺伝している ことを確認した。このVNTR 遺伝子がへテロ 接合体である頻度は46\%（23/50）であり，PIC

(Polymorphism information content) は0.35 であった。それぞれの遺伝型で出現頻度の実測 值と期待值から計算したカイ 2 乗値は8.25( $\mathrm{df}=$ 9, $\mathrm{p}=0.5)$ で（表 1)。本 VNTR 遺伝子には Hardy-Weinberg の平衡式が成立すると考之ら れた.

2. 正常日本人における第20番イントロン内 VNTRの多型性

この VNTRの骨格となる塩基配列は CTTT (T)の繰り返し構造であり,理論的には 1 塭基対 の差を検出することが可能であるといわれてい る ${ }^{12)}$. しかし，本研究で用いた泳動条件では，4 bpの差がかろうじて検出可能であった.従って, PCR 産物の塩基長は $4 \mathrm{bp}$ の間隔で恣意的に定

表 $2 \mathrm{RB} 1$ 第20番イントロン内 VNTR 遺伝型の実測值と期待値とのカイ 2 乗検定

\begin{tabular}{|c|c|c|c|c|c|c|c|}
\hline 遺伝型 (bp) & 実測值 & 期待值 & $x^{2}$ 値 & 遺伝型 & 実測值 & 期待値 & $\boldsymbol{x}^{2}$ 值 \\
\hline $192 / 192$ & 2 & 0.61 & 3.22 & $200 / 240$ & 4 & 2.87 & 0.44 \\
\hline $192 / 196$ & 0 & 0.55 & 0.55 & $204 / 204$ & 1 & 0.25 & 2.33 \\
\hline $192 / 200$ & 6 & 4.51 & 0.49 & $204 / 208$ & 2 & 1.61 & 0.09 \\
\hline $192 / 204$ & 0 & 0.77 & 0.77 & $204 / 216$ & 0 & 0.07 & 0.07 \\
\hline $192 / 208$ & 1 & 2.53 & 0.93 & $204 / 224$ & 0 & 0.28 & 0.28 \\
\hline $192 / 216$ & 0 & 0.11 & 0.11 & $204 / 236$ & 0 & 0.07 & 0.07 \\
\hline $192 / 224$ & 0 & 0.44 & 0.44 & $204 / 240$ & 0 & 0.49 & 0.49 \\
\hline $192 / 236$ & 0 & 0.11 & 0.11 & $208 / 208$ & 6 & 2.65 & 4.26 \\
\hline $192 / 240$ & 0 & 0.77 & 0.77 & $208 / 216$ & 0 & 0.23 & 0.23 \\
\hline $196 / 196$ & 1 & 0.13 & 6.13 & $208 / 224$ & 0 & 0.92 & 0.92 \\
\hline $196 / 200$ & 2 & 2.05 & 0 & $208 / 236$ & 0 & 0.23 & 0.23 \\
\hline $196 / 204$ & 1 & 0.35 & 1.21 & $208 / 240$ & 1 & 1.61 & 0.23 \\
\hline $196 / 208$ & 0 & 1.15 & $1.15^{\prime}$ & $216 / 216$ & 0 & 0 & 0.01 \\
\hline $196 / 216$ & 0 & 0.05 & 0.05 & $216 / 224$ & 0 & 0.04 & 0.04 \\
\hline $196 / 224$ & 0 & 0.20 & 0.20 & $216 / 224$ & 0 & 0.01 & 0.01 \\
\hline $196 / 236$ & 0 & 0.05 & 0.05 & $216 / 240$ & 0 & 0.07 & 0.07 \\
\hline $196 / 240$ & 0 & 0.35 & 0.35 & $224 / 224$ & 0 & 0.13 & 0.13 \\
\hline $200 / 200$ & 8 & 8.41 & 0.02 & $224 / 236$ & 0 & 0.05 & 0.05 \\
\hline $200 / 204$ & 2 & 2.87 & 0.26 & $224 / 240$ & 1 & 0.28 & 1.85 \\
\hline $200 / 208$ & 7 & 9.43 & 0.63 & $236 / 236$ & 0 & 0 & 0.01 \\
\hline $200 / 216$ & 1 & 0.41 & 0.85 & $236 / 240$ & 1 & 0.07 & 12.36 \\
\hline $200 / 224$ & 3 & 1.64 & 1.13 & $240 / 240$ & 0 & 0.49 & 0.49 \\
\hline $200 / 236$ & 0 & 0.41 & 0.41 & & & & \\
\hline
\end{tabular}


義した. また, 本 VNTR の増幅は第17番イン トロン内 VNTR と比較して効率が悪く, Brandt らの原法 ${ }^{12)} に$ 記載されている denature を10秒 より15秒に, anealing を10秒より15秒に, extensionを 20 秒より 30 秒に改変して初めて良好な增 幅を得た。しかし，非特異的なバンドの増幅が いかなる PCR 条件でも認められた，正常日本 人 50 症例における第 20 番イントロン内 VNTRに は192bp, 196bp, 200bp, 204bp, 208bp, 216bp, $224 \mathrm{bp}, 236 \mathrm{bp}$ および240bpの少なくとも 9 種類 の对立遺伝子が存在していた(図 4).その出現 頻度はそれぞれ0.11，0.05，0.41，0.07，0.23，

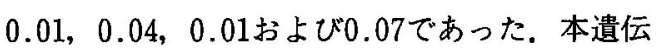
子は codominantに遺伝しておう，へテロ接合 体の頻度は64\% (32/50)で, PIC は0.74であっ た。なお，それぞれの遺伝型で出現頻度の実測 値と期待值より計算したカイ 2 乗值は 44.1 ( df 44, $\dot{\mathrm{p}}=0.5$ ）（表 2）で Hardy-Weinberg の平 衡式が成立していた。

3. 遺伝性 $\mathrm{Rb}$ 家系の発症前診断および染色体 異常の親の起源への VNTR 多型性の応用

\section{1) 家 系 1}

第17番イントロン内 VNTR 多型を応用した ところ (図 5)，父親は $1400 \mathrm{bp}$ と $1500 \mathrm{bp}$ のへテ 口接合体，母親は $1400 \mathrm{bp}$ のホモ接合体であった. 患者である第 1 子は $1400 \mathrm{dp}$ と $1500 \mathrm{bp}$ のへテロ

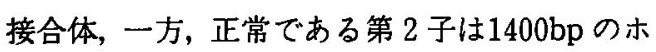
モ接合体であり，父親の $1500 \mathrm{bp}$ を含む染色体に RB1 遺伝子の異常が存在すると考えられた。第

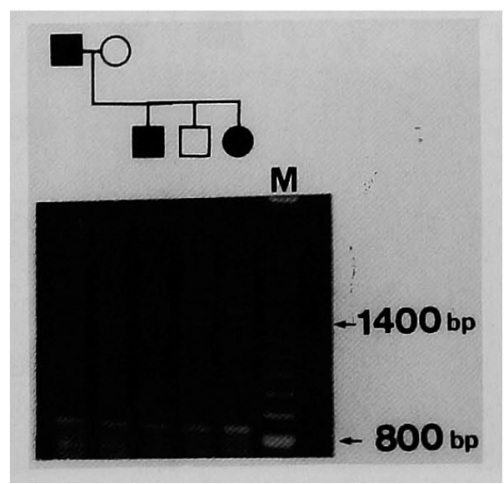

図 5 第17番イントロン内 VNTR の多型性の家系 1 への応用
3 子は $1400 \mathrm{bp}$ と $1500 \mathrm{bp}$ のへテロ接合体であり， 患者と診断された。つぎに，第20番イントロン 内 VNTR の多型性を応用したところ（図 6), 父親は $204 \mathrm{bp}$ と $240 \mathrm{bp}$ とのへテロ接合体，母親 は200bp と208bp とのへテロ接合体, 第 1 子は $200 \mathrm{bp}$ と $204 \mathrm{bp}$ とのへテロ接合体, 第 2 子は 200 bp と240bp とのへテロ接合体であり, RB1 遺 伝子の異常は父親の $204 \mathrm{bp}$ を含む染色体に存在 することが判明した。第 3 子は $200 \mathrm{bp}$ と204bp と のへテロ接合体であり，患者であると猃断した。 なお, 第 3 子は, 生後 4 力月に両眼球に $\mathrm{Rb}$ が 発生し, 両側網膜凝固療法を受けた。

2) 家 系 2

第17番イントロン内 VNTR 多型性の応用で は, 父親, 母親, 第 1 子およU゙発端者である第 2 子いずれも $1400 \mathrm{bp}$ のホモ接合体であり，情報 は得られなかった.しかし，第20番イントロン 内 VNTR 多型性の応用では(図 7), 父親は 192 bp と $196 \mathrm{bp}$ とのへテロ接合体，母親は $200 \mathrm{bp}$ と 204bp とのへテロ接合体, 患者である第 1 子は $192 \mathrm{bp}$ と200bp とのへテロ接合体であり, 父親 の RB1 遺伝子異常は192bp を含む染色体に存 在することが判明した.第 2 子は196bp と204bp とのへテロ接合体であり, 正常であると診断し た.

\section{3) 家系 3}

第17番イントロン内 VNTR 多型性の応用で

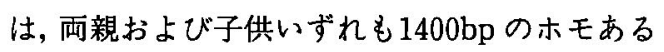
いはへミ接合体であり, 染色体異常の親の起源 に関し有用な情報は得られなかった。しかし，

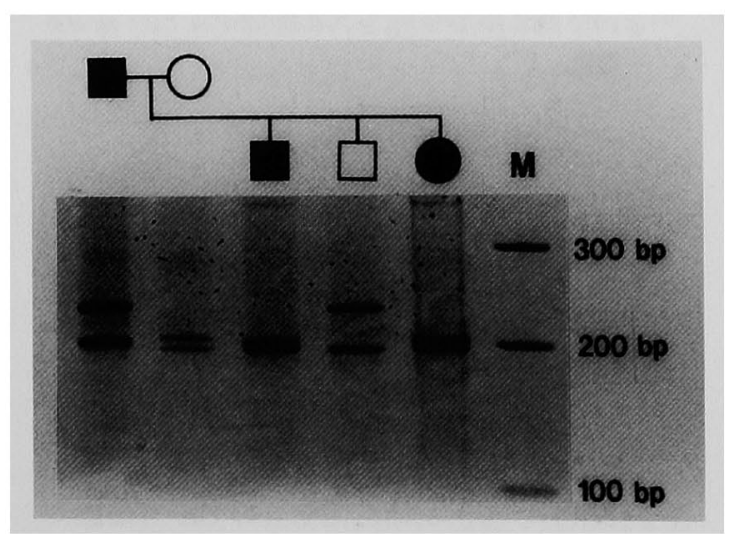

図 6 第20番イントロン内 VNTR の多型性の家系 1 への応用 
第20番イントロン内 VNTR の多型性の応用で は(図 8 ), 父親は $188 \mathrm{bp}$ と $196 \mathrm{bp}$ とのへテロ接 合体，母親は200bp と240bp とのへテロ接合体 であった．患者である子供は240bp のみのへミ 接合体であったので，父親の対立遺伝子が存在 する染色体が欠失したと診断した。

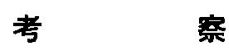

$\mathrm{Rb}$ の原因遺伝子がクローニングされた現在, $\mathrm{Rb}$ の遺伝相談には遺伝子診断は不可欠である. 遗伝子診断により，高りスクの保因者で早期の 診断と治療により，視力が温存される機会が增 加し，非保因者で危険を伴う全身麻酔下の頻回 の眼底検查を回避することが可能となる。しか し，遺伝性 Rb の遺伝解析で，染色体レベルで 検出可能な異常が $8 \%{ }^{14)}$, サザンブロット分析で 検出可能な異常が10～20\%と報告されており ${ }^{15)}$, 多くの症例は点突然変異あるいは微細な欠失で あることが推測されている. RB1 遺伝子の全塩 基配列の決定に費やされる労力と時間の観点か ら，より迅速で実用的な方法の開発が要求され ている。本研究では，個人識別にもっとも有効 な VNTR の多型性を用いて RB1 遺伝子異常 が存在する染色体を判別した，日本人における $\mathrm{RB} 1$ 第17番および20番イントロン内 VNTRの 多型性を検討した結果， 4 および 9 種類の対立 遺伝子が存在しており，へテロ接合体の頻度は それぞれ46\%および64\%であった。これらの 2 つの VNTRの多型性の応用により，遺伝性 Rb 3 家系で出生前診断あるいは親の起源の決定が

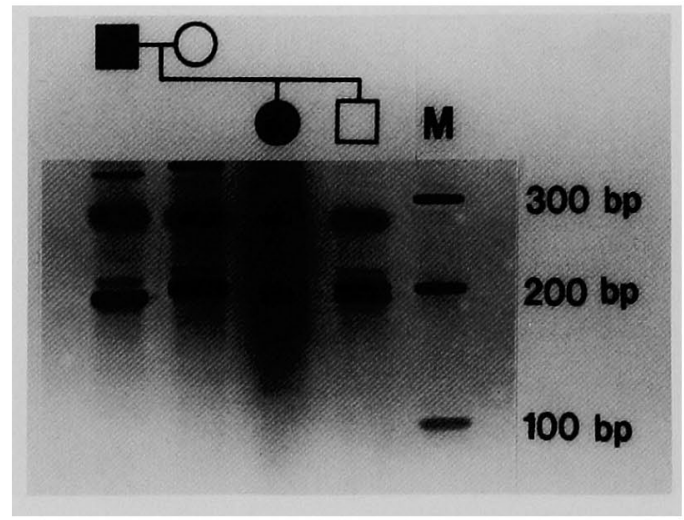

图7第20番イントロン内 VNTR の多型性の家系 2 への応用
可能であった.

RB1 の遺伝子解析より，第17番イントロンに は RsaI などの制限酵素で多型を示す VNTRの 存在が知られていた8). Scharf ら ${ }^{111}$ はこのイン トロンの塩基配列より VNTR を特異的に増幅 するPCR 法を開発し，250人の試料から 650 1800bpにわたる11種類の対立遺伝子を同 定した. へテロ接合体の頻度はコーカサス人， アフリカ系アメリカ人，スペイン系アメリカ人 およびスペイン系メキシコ人でそれぞれ $62 \%$ ， 75\%，61\%および50\%であった．最も共通した 対立遺伝子はコーカサス人，スペイン系アメリ カ人およU゙スペイン系メキシコ人で1450bpであ $\eta$ ，全対立遺伝子の59 69\%を占めていた。 一 方,アフリカ系アメリカ人では $1500 \mathrm{bp}$ と $1450 \mathrm{bp}$ の対立遺伝子が最も多く認められ，コーカサス 人とアフリカ人との中立的な民族の混合が示焧 された。日本人では 4 種類の対立遺伝子のみが 存在していたが，最も共通した対立遺伝子は，

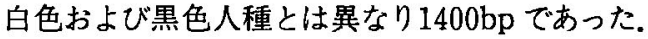
日本人ではこの共通した対立遺伝子の頻度は 73 \%と高率のため，へテロ接合体の比率が低く， 遺伝性 $\mathrm{Rb}$ 家系の連鎖解析で有用な情報を得る 機会が少ないと考えられた，しかしながら，第 17番イントロン内 VNTR の PCR 法による增 幅は，エチジウムブロマイド染色で繰り返しの 最小単位の54塩基対の差を容易に検出できるも のであり，個人識別に非常に有効であると考え

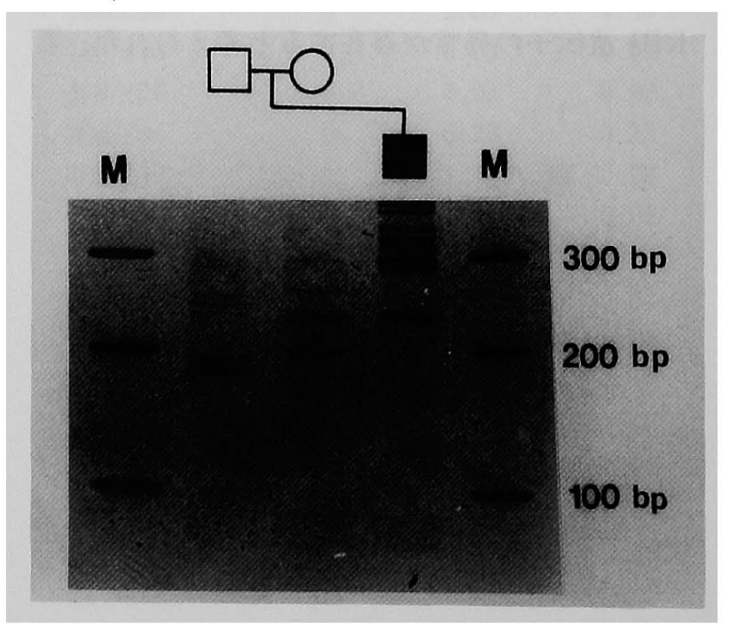

図 8 第20番イントロン内 VNTRの多型性の家系 3 への応用 
られる。

これとは対照的に, 第20番イントロン内 VNTR には日本人においても少なくとも 9 種類の对立 遺伝子が検出され，へテロ接合体の頻度は $64 \%$ であった。これらの対立遺伝子は均等に分布し ており，最も高頻度の200bp の対立遺伝子でも 41\%を占めるにすぎなかった.この VNTR 多 型性の連鎖解析における情報性は高く（PIC= $0.74)$, 遺伝性 Rb 3 家系すべてにおいて発症前 診断あるいは染色体異常の親の起源の決定に応 用可能であった.

第20番イントロン内 VNTR の存在は Yandell とDryja ら ${ }^{12)} に よ り$ 初めて報告された。彼らは CTTT (T)の繰り返し構造を含む550～600bp 領

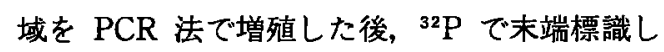
たプライマーでシークエンス反応を行い，オー トラジオグラフィーで PCR 産物の塩基長を決 定した。本研究では彼らの方法を改変した Brandt ら14の方法を使用した。その方法はさらに短い部 分を PCR 法で増幅し, 制限酵素 BstN I で non-repeat 部分を切断した後, 分離するもので ある。検出には，オートラジオグラフィーでは なく，銀染色を応用しており，簡便性ばかりで なく安全性からも優れた方法といえる. 本研究 で明らかにした日本人のへテロ接合体の頻度 $(64$ \%) が Yandell と Dryja の報告 (94\%) と比 して低率であったことは，民族特異性というよ $\eta$, 電気泳動法の分離能に依存していると考之 られる. 本研究で使用した $10 \times 10 \mathrm{~cm}$ のゲルでは 1 塩基の差を分別することが不可能であり，比 較的低鎖長での 1 塩基差のへテロ接合体や比較 的高鎖長での 4 塩基差のへテロ接合体をホモ接 合体として認識した可能性が否定できない。シ ークエンシングゲル泳動法や高精度ポリアクリ ルアミドゲル泳動法 ${ }^{16)}$ 态用すれば, 検出可能な 対立遺伝子の種類はさらに增加すると思われる。

13番染色体欠失を合併した两側性 $\mathrm{Rb}$ の家系 3 では，第20番イントロン内 VNTR 多型の応 用から，欠失の染色体起源は父親であることが 確認された。体細胞の13番染色体に欠失あるい は転座が認められた Rb13例の研究で, 有用な情 報が得られた 9 例のうち 8 例では染色体異常が 父親に由来していた ${ }^{14)}$. 一方, $\mathrm{Rb}$ 腫場細胞にお
ける RFLP マーカーを用いたへテロ接合性の消 失 Loss of heterozygosity (LOH)の研究では ${ }^{17)}$, 片側性腫瘍 10 例のうち 4 例で父親の対立遺伝子 のみが残存したのに対し，両側性腫堭 14 例のう ち13例では父親の对立遺伝子のみが残存してい た. $\mathrm{Rb}$ の体細胞ではどちらの親の対立遺伝子が 残存するか選択されないが, 生殖細胞では父親 の对立遺伝子（染色体）に変異が起こりやすい ことが考えられる.この親の選択性の理由とし て,精子の対立遺伝子が突然変異を受けやすい, あるいは易変異性が父親由来の染色体に刷り込 まれているとする genomic imprinting 説のい ずれかが推測されている18).

散発性の $\mathrm{Rb}$ 症例における遺伝子診断は, $\mathrm{Rb}$ が子孫に遺伝するかどうかの予知に必要である. かかる症例における RB1 遺伝子の多型性の応 用には限界が存在する。従来, $\mathrm{Rb}$ 発生には $\mathrm{LOH}$ が重要であると報告されれてるる ${ }^{19}$.しかし, 腫瘍 細胞にたとえ LOH が証明されても，多型性だ けの応用では $\mathrm{Rb}$ 遺伝子異常が生殖細胞あるい は体細胞のいずれに発生したかを決定すること は困難である. RB1 の遺伝子変異を検出する方 法としてRT-PCR が報告されている20).この方 法は, 細胞の mRNA から逆転写酵素により合 成した CDNA を用い遺伝子変異を検出するもの であるが, 変異遺伝子からの mRNA の発現が 抑制されている正常体細胞には応用できない． この抑制は，とくにフフレームシフトにより途 中に停止コドンを生じるような変異で知られて おり ${ }^{21)}$ ，RB1 の転写が正常 RB1 から作られる $\mathrm{Rb}$ 蛋白により制御される説が提唱されている22). Yandell ら ${ }^{23)}$ は腫瘍細胞および体細胞の DNA から全エクソンを PCR 法により增幅し，その 塩基配列を決定した結果, 散発性で两側性の Rb4 例のうち 3 例で生殖細胞レベルの突然変異を検 出した.この方法は多大の労力と時間を必要と するものであるが, 散発例の遺伝性 $\mathrm{Rb}$ の予知 において唯一有効であると考えられる。

\section{結論}

遺伝性 $\mathrm{Rb}$ の発症前診断に迅速で実用的な方 法を開発することを目的に, PCR 法により RB1 遺伝子第17番およU゙20番イントロン内 VNTRの 
多型性を正常日本人 50 症例で検討し, 遺伝性 $\mathrm{Rb}$ 3 家系の発症前診断あるいは染色体異常の親の 起源の決定に応用した。 日本人の第17および20 番イントロン内 VNTR には，それぞれ 4 およ び 9 種類の対立遺伝子が認められ，へテロ接合 体の頻度はそれぞれ46および64\%であった。こ れらのVNTR の遺伝型の頻度は, 対立遺伝子 の頻度から算定した遺伝型の期待度数と相反し なかった。第17番イントロンVNTR 多型性の 応用では 1 家系において，第20番イントロン VNTR の応用では，3 家系すべてにおいて，診
断に有用な遺伝情報が得られた. PCR 法による 第17番および20番イントロンVNTR の多型性 の解析は, 遺伝性 $\mathrm{Rb}$ の発症前診断や遺伝子あ るいは染色体異常の親の起源の決定に確実かつ 実用的であると考えられた。

稿を終之るあたり，御指導，御校閲を賜りました 岡山大学医学部小坚科学教室清野佳紀教授に深く感 謝致します。また, 終始直接に御指導, 御教示いた だきました㫮原幸二助教授に深謝いたします。

\section{文}

1) Devesa MHS: The incidence of retinoblastoma. Am J Ophthalmol (1975) 80, 263-265.

2) Vogel F : Genetics of retinoblastoma. Hum Genet (1979) 52, 1-54.

3) Knudson AG : Mutations and Cancer : Statistical study of retinoblastoma. Proc Natl Acad Sci USA (1971) 68, 820-823.

4) Sparkes R, Sparkes M and Wilson M : Regional assignment of genes for human enterase D and retinoblastoma to chromosome band 13q14. Science (1980) 208, 1042-1044.

5) Friend SH, Bernards R, Rogelj S, Weinberg RA, Rapaport JM, Albert DM and Dryja TP : A human DNA segment with properties of the gene that predispose to retinoblastoma and osteosarcoma. Nature (1986) 323, 643-646.

6) Lee WH, Bookstein R, Hong F, Yong LJ, Shew JY and Lee YH : Human retinoblastoma susceptibility gene : cloning, identification, and sequence. Science (1987) 235, 1394-1399.

7) Horsthemke B, Barnet HJ, Greger V, Passarge E and Höpping W : Early diagnosis in hereditary retinoblastoma by detection of molecular deletion at gene locus. Lancet (1987) I, 511-512.

8) Wiggs J, Nordenskjöld M, Yandell D, Rapaport J, Grondin V, Janson M, Werelius B, Petersen R, Craft A, Riedel K, Liberfarb R, Walton D, Wilson W and Dryja TP : Prediction of the risk of hereditary retinoblastoma, using DNA polymorphisms within the retinoblastoma gene. $\mathrm{N}$ Engl J Med (1988) 318, 151-157.

9) Nakamura Y, Leppert M, O'Connell P, Wolff R, Holm T, Culver M, Martin C, Fujimoto E, Hoff $\mathrm{M}$, Kumlin $\mathrm{E}$ and White $\mathrm{R}$ : Variable number of tandem repeat (VNTR) markers for human gene mapping. Science (1987) 235, 1616-1622.

10) Jeanpierre M : A rapid method for the purification of DNA from blood. Nucleic Acids Res (1987) 15, 9611.

11) Scharf SJ, Bowcock AM, McClure G, Klitz W, Yandell DW and Erlich HA : Amplification and characterization of the retinoblastoma gene VNTR by PCR. Am J Hum Genet (1992) 50, 371-381.

12) Yandell DW and Dryja TP : Detection of DNA sequence polymorphisms by enzymatic amplification and direct genomic sequencing. Am J Hum Genet (1989) 45, 547-555.

13) Brandt B, Greger V, Yandell DW, Passarge E and Horsthemke B : A simple and nonradioactive method for detecting the Rbl. 20 DNA polymorphism in the retinoblastoma gene. Am J Hum Genet (1992) $51,1450-1451$. 
14) Ejima $Y$, Sasaki MS, Kaneko $A$ and Tanooka $H$ : Types, rates, origin and expressivity of chromosome mutations involving 13q14 in retinoblastoma patients. Hum Genet (1988) 79, 118-123.

15) Goddard AD, Balakier H, Canton M, Dunn J, Squire J, Reyes E, Becker A, Phillips RA and Gallie $\mathrm{BL}$ : Infrequent genomic rearrangement and normal expression of the putative RBl gene in retinoblastoma tumors. Mol Cell Biol (1988) 8, 2082-2088.

16) Budowle B, Chakraborty R, Giusti AM, Eisenberg AJ and Allen RC : Analysis of the VNTR locus DIS80 by the PCR followed by High-resolution PAGE. Am J Hum Genet (1991) 48, 137-144.

17) Zhu X, Dunn JM, Phillips RA, Goddard AD, Paton KE, Becker A and Gallie BL : Preferential germline mutation of the paternal allele in retinoblastoma. Nature (1989) 340, 312-313.

18) Hall JG : Genomic imprinting : Review and relevance to human disease. Am J Hum Genet (1990) 46, $857-873$.

19) Dryja TP, Cavenee W, White R, Rapaport JM, Petersen R, Albert DM and Bruns GA: Homozygosity of chromosome 13 in retinoblastoma. N Engl J Med (1984) 310, 550-553.

20) Dunn JM, Phillips RA, Becker AJ and Gallie BL : Identification of germline and somatic mutations affecting the retinoblastoma gene. Science (1988) 241, 1797-1800.

21) Dunn JM, Phillips RA, Zhu X, Becker and Gallie BL : Mutations in the RB1 gene and their effects on transcription. Mol Cell Biol (1989) 9, 4596-4604.

22) Yandell DW, Campbell TA, Dayton SH, Petersen R, Walton D, Little JB, McConkie-Rosell A, Buckley EG and Dryja TP : Oncogene point mutations in the human retinoblastoma gene : their application to genetic counseling. N Engl J Med (19̀89) 321, 1689-1695. 
VNTR polymorphism in the 17th and 20th introns of the RB1 gene in Japanese and its application to genetic counseling in hereditary retinoblastoma

Shinsuke NinomiYa

Department of Pediatrics, Okayama University Medical School,

Okayama 700, Japan

(Director : Prof. Y. Seino)

Risk estimation for siblings or offspring is important in genetic counseling of patients with hereditary retinoblastoma. The RB1 gene spans approximately $200 \mathrm{~kb}$ in length, containing 27 exons. The use of polymorphic markers within the RB1 gene will eliminate the need of laborious specification of a mutation. The present study determined types and frequencies of VNTR polymorphisms of the 17th and 20th introns of the RB1 gene in 50 unrelated Japanese, using PCR amplification. In the 17th intron VNTR, there were 4 alleles, which ranged from $1400 \mathrm{bp}$ to $1550 \mathrm{bp}$. The most common allele was $1400 \mathrm{bp}$ with a frequency of $73 \%$, and the heterozygosity rate was $46 \%$. In the 20 th intron VNTR, there were at least 9 alleles, wihch ranged from $192 \mathrm{bp}$ to $240 \mathrm{bp}$. The alleles were more evenly distributed than those of the 17th intron VNTR, and the heterozygosity rate was $64 \%$. These VNTR polymorphisms were successfully applied to the prediction of retinoblastoma and to the determination of parental origin of a chromosome deletion in 3 families with hereditary retinoblastoma. Analysis of VNTR polymorphisms within the RB1 gene proves to be practical and efficient for risk estimation in hereditary retinoblastoma. 